EFH;PTH: JHIIC $\mathrm{V}-1$
U. S. DEPARTIENT OF COIIERCE

NATIONAL BUREAU OF STANDARDS

WASHINGTON

November 22, 1946
Letter

Circular

$\operatorname{LC} 837$

( Lu304)

PAINTING INTERIOR WALLS AND TRIM

By E. F. Fickson and P. T. Hovard

Introduction

Contents

Page

1

Types of interior paints . . . . . . . . . . . . 2

Tall primers . . . . . . . . . . . . . . . 2

One-coat flats .................. 2

Flat, semigloss and giloss oil paints . . . . . . . 2

Water paints ................ 3

Painting walls and ceilings . . . . . . . . . . . 3

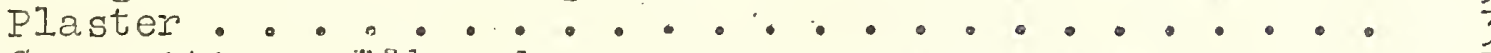

Composition walliboard............... 5

Fabric . . . . . . . . . . . . . . . . . 6

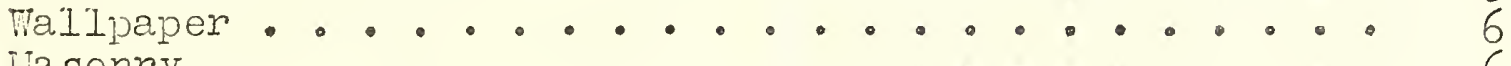

lia sonry ................... 6

Painting interior trim . . . . . . . . . . . . . 6

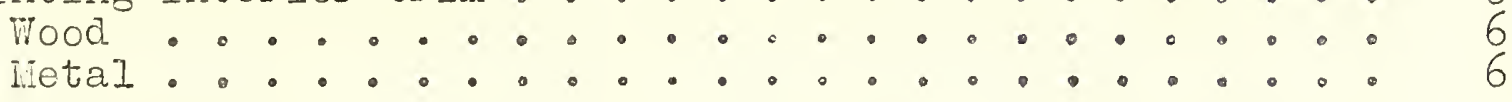

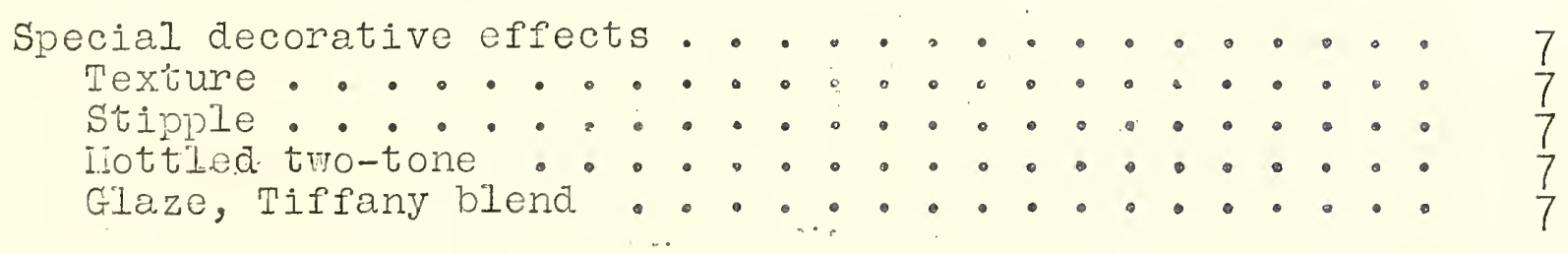

Publications ...................... $\delta$

\title{
INTRODUCTION
}

The paint industry selis annually in this country upwards of 700 milizon doIlars vorth of paint and varnish products. A large percentagë of these coatings is used on the interior of structures. Their main use is to obtain pleasing decorative effects, but also they are ridely applied to improve sanitary conditions, to provide better lighting, to promote safety in machine operation by the proper use of color on equipment and walls, and to serve a variety of other special needs. 
This letter circular is designed to answer a large volume of requests received by this Bureau for information on painting interior surfaces, particularly mood and plaster. There is.presented a general description of interior paints and a discussion of painting problems. Painting procedures of general applicability are suggested. Necessarily many oz the recomendations are quite general, and they are not intended to supplant manufacturers' directions for the use of particular proaucts consideration is given on! y to typegloI paint that are regularly obtainable and to the conventional surfaces to which they are applied. No attempt has been made to present solutions to unusual problems which may be encountered, and the relation of plaster to paint failure also is dealt with only superficially. Understandably, no information is given on brands of paint。

\section{TYPES OF INTERIOR PAINTS}

Wall.primers.- Wall, primers, or.primer-sealors as they are sometimes called, are intonded to be applied directly to bare plaster, waliboard, and. similar.porous surfaces. They may accompilsh. various. things, depending. on the aims and ability of the formulator. Their main. purpose, horever, is to provide a uniform, sealea surpace for subsequent coats of paint. A typica! product is made from. a. vainish. or bodied. ojl vehjcle. inthich a hoderate amount of hiding pigments of nediun or high strengith together with inert.pigments are ground, in order to give a product of at least moderativ good. hjaing power and a fair degree of gloss in the dised. film. Such,a. formulation is intended to peneirate only slight! into porous surfaces, and to be easily applied with a wide wa11.brush. Federal, Specification TT-P-56. describes a primer.mealer. suitable for use on plaster and. wạliboard.

Qne-coat. flats- One-çoat flat paịts are organic-solventthinned paints intendeda.to accomplish priming, sealing, and finish coating.iz one petiation. They are oftẹn. sọld in thin paste form so that adaitional inexpensive thinner maj be added and mixed before application to increase the volune by one-fourth or more. To kecp.as much.of the film on the surface as possible, paints of this.type usually utilize the non-penetrating principle to a high degree. Federal. Specification, TI-P-47 covers a one-cont flat type.of rinish.

Flat, semigloss, and. gloss.paints.- Flat, semigloss, and gloss interior paints and encme vary in composition as necessary to produce the desired degles of gioss. liding pover, and other properties. Best hiding powe. Ion paints of a given lightness is normally asscclated with palrse of lovest gloss, although some modern high-gloss enanels vitistng Iull-strength, high-hiding pigments have this proptet to k high degees. sederai specifi-

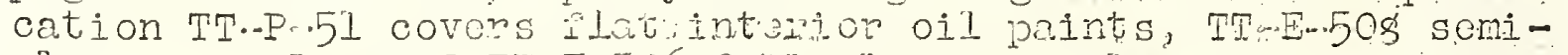
gloss enaneIs, and TI-E-506 full gloss enamels, 
Flat and semigloss interior paints ma also be prepared from paste white lead and a suitable vehicle. Directions for application subsequently given apply both to these paints and to the readyamixed tipe.

Water paints.- Water-thinned interior paints are exempified by calcimine, cassein (or other protein) jaints, resin emulsion, and the new gloss rater paints. Calcimine is supplied in powder form. It consists essentially of whiting and clay intimately mixea.with an animal glue binder, together with a preservative. Calcimine can be washed off easily irom the wall before redecorating. There is a type suitable f"or mixing yith hot water and one for use with cold water. Federal Specification TT-C-96 covers both types. Paints employing casein or soya protein are sometimes referred to as "washable" calcimines, although their formulation is more complex than calcimine, with the proteins used as the birider instead of glue." Both powder and paste forms are avalable and both are designed for mixing vith rater at noderate temperature. Federal Specification TT-P-23 covers the powdor and paste forms. The desire for something better than the vater paints just described led to the resin emulsian peints, thich are nerketed in paste form and are usually designed for thining with water in the proportion of onewhalf gallon of water to one gallon of paste. These paints usualdy have an oleoresinous binder dispersed in water (emulsified drving oils or varnishes) and are stabilized with protein so that they have some. of the characteristics of both the mater-thinned and organic-solvent-thinned types. They may be decidedly complex in nature and difficult to formulate. When properly made and applied, resin emulsion paints adhere teñoiously to plaster and provide a good decorntive redium. They need not be penoved kefore redecoratine, provided the film is in sound condition. Federal jogifichion m-p.-88 covers resin emulsion paints, Wror winnedpathts are relatively nev at this miting and comsequently have not been as ridely used nor as, thoroughly investignted as the flat finish type, although the fact that they can be procued cormercially is acknoriedged in the trade to be a techica. achívement of nerit.. They are knom to be characteized by unusvally good busing properties, hovever, for a'gloss prodict. There is no Federil'specilication at present for this material.

\section{PAINTING WALLS. AND CEILINGS}

Plaster.- Plaster is one of the rost difficult surfaces to paint successully. The reasons for this are not difficult to understand. Unlike steel, plaster is porous (and of varying porosity). Unlike wood, rhich is porous also, plaster contains materials of an alkaline nature which tend to have a destructive action toward oil paints. Adaed to this is the'fact that new plaster contains large anouns of vater; noreover the plaster is uslunly rplited to porous naterials (brick, for examie). Thich are also vet. It is estinated that the we.ter in the brickrork and plaster of an average room after just being constructed is about one ton. Even under ordinary good drying conditions, many 
nonths are requirea for this mater to evaporate. If the surface is sealed with peint, arying is prolonged still further. Thus if it vere possible to avoid painting until the structure becane dry, many painting difficulties vould aisappear.

Paint failures over plaster may take various forms, but one of the rnost objectionable and certainly one of the most comon forms is that ol flaking, in which smal pieces of film becone detached and fall from the surface. Other forms of failure in clude scaling or peeling of relatively large pieces of film, softening and darkening of the paint, the, development of glossy or dull spots, change of color of some paints, etc.

The causes of some of these types of fallure are known, others are suspected, and sore are not knom. The plnster surface itself may be inferior because of the use of poor riaterials. improper proportioning and mixing of ingredients, or of imperfect technique op the plasterer. While it is obviously imossible to determine the existence of some of these potential sources. of paint failure, others can be recognized and avoided.

As has been previously stated, nevly laid plaster contains a large volume of water which, if not allored to dry out beiore. painting, may exert mechanical action to loosen a paint filn. In addition to the loss of adhesion by mechanicrl action, the presence of water, hydrated lime, and alkali salts fromthe water, brick, sand, etc.) cause a chemical action ("saponification"); the rilm becones soitened and sticky, and bromish arops (saponified oil) may appear on the' surface of the paint. Besides attacking the oil, certain pignents such as chrome green and Prussian blue becone bleached or discolored by the alkaline vater. Likerise, soluble salts present in nost building naterials (in the sand and cenent of the nortar, in the water, in the plaster undercoats, in the finish plaster, etc.) are sometines carried to the surface and appear as a "rhite powder or "efflorescence". When this iorms underneath the paint, general peeling and faking occur. Saponim ilcation nd efflorescence are apt to occur together. A slow water leak extending over a considerable period of tine so that the vater saturates the plaster is almost certain to result in saponification followed. by efflorescenco.

While moisture and the presence of alkali have been blamed for many paint failures for which they probably were not responsible, it is nevertheless wise to avoid this condition whenever possible. This applies to moisture rhich ma reach the plaster subsequent to drying as well as to thet originally present in the wet coat. 
other conditions that can be detected and avoided are soft spots in the plaster, badiy cracked areas, pordery surfaces, and varicolored areas. Some of these conditions may not be certain to cause paint failure while otiers alnost certainly rill. A first-class re-plastering of the affected areas minere the more serious defects exist is indicated if it is desired to reduce to a minimum the possibility of paint failure.

Nev ary plaster in good condition, which is to be finished witin a paint other than water paint, should be given a coat of primer-sealer, and this should be alloved to dry thoroughly and then inspected for uniformity of appearance. Particular note should be made of variations in gloss and, in the case of tinted priners, of color differences. If there is non-uniformity, it may be advisable to recoet the entire surface with the prining paint. Hovever, if only a fer "suction spots" are apparent, a second cort over these areas may be sufficient. It is very important thet tire disy, unpainted plaster be mae uniforn as to color, gloss, nnd appenance by means of the primer-sealer before applytig finishing coats of paint. Uniforn surface conditions are particularly important if the finish coat is to be a semigloss or gloss product. one cort of flat finish paint is often sufficient over a properly primed and sealed surface, although a second coat nay be aplied if desired. Semigloss and gloss paints and enameIs usualiy require special undercoaters as an internediate coat, but in some instances they nay be applied directly to the primed surface. It is important to follow the manufacturer's directions in using these materials if a surface of uniform appearnice with respect to gloss and color is to be obtained.

Before applying rater paints of the calcimine type to new plastered walls they should be sized, using either a glue-water size or, if the plaster is dry, a thin variish or primermsealer. Cold water paints of the protein type (casein or similar binder) may be applied either directly to a plastered surface, or the surface may first be. Given a coat of primer-sealer to equalize uneven suction effects. The same is true of resin emulsion paints, with the recommendations of the manufacturer of the product being given preference in any case of doubt. Since resin emulsion paints usually contain some oil in the binder, they should ordinarily be applied only to plaster which has dried thoroughly.

Composition vallboard.- Composition wallboard usually presents no particular painting difficulties if the ordinary precautions are observed, sucin as maing certain that the surface is dry and free from grease or oil. In general, the painting procedure is the same as for plaster; a priming and sealing coat is required, followid by whatever finish conts are desired. If it is desired to restrict the painting systen to one cort, the previously described one-coat flat or resin emulsion type paints may be used. These paints combine a prining and sealing action with their other characteristics. 
Fabrics.- Fabrics such as canvas or muslin, which are very absorbent, should be given a coating of glue size and allowed to dry before appliction of an oil paint. Resin emulsion paints could probably be applied directly to the unsized fabric if the paint for the first cont were thinned suficiently with vater. Fabric painting, however, may be a special problen, and it is suggested that in any, case of doubt advice on the particular problen at hand bo obtained before proceeding.

WaIlpaper.- Paint may be applied over wallpaper if the latter is reil bonded to the rall, does not contain dyes which rill bleed. into the paint, and there are not too many thicknesses of paper on the val1 - it is preferable to have not yore than one Iiuch of the popularity of resin enulsion paints is due to the fact thet rany of then have been developed: for applicrtion over paper. Directions for application are usuolly printed onthe label of the container. Paints other than those of the rater-thinned type nay also be used for this purpose by following the directions given for painting plaster. It nay be pointed out, hovever, thit vallpaper under such a paint syster is very difficult to renove without injury to the plaster.

Masonry.- Interior rasonry walls and ceilings nay, in general, be painted in much the same ranner as plaster surfaces. Here again, it is necessary to allow adequate time for drying, and in addition some attention must be given to the preparation of the surface. When decornting, a riaterial containing Portland cement (concrete, for exarple), it is éssentinl to take special precautions against the attack of alkali. Alkali-resistant priners should be used (preferably in two conts) when oil paints are to follow, and limeresistant pigments should be used. The details of a recomended procedure for the latter are given in National Burenu of Standards Letter Circular LC747, Painting Exterior Walls of Porous liasonry.

\section{PAINTING INTERIOR TRIII}

Wood.-..New interior wood trim should be snoothed with sandpaper and austed berore painting. Proprietrry seminloss enamels thinned vith one pint of turpentine per gallon of paint or a similar material prepared fron paste tritte lead my be used as a first coat. The prire-sedier previously dercibed for use on tralls may also be used for this purpose. One or two coats of semigloss enanel should then be applied over the thoroughly dry prine coat, or if a full gloss finish is ctestred the last coat silould be of that material

Metal.- Ney interior rtetal trin should be cleaned to remove all rust, dirt, "and grease and then given a coat of red lead or other rust-inhikiting paint. After ample tine has been alloved for drying, particulariy if a Iinseed oilmed lead priner is used, the finish coats should be applied in the sane nanner as has been indicated for rood trin. 


\section{SPECIAL DECORATIVE EFEECTS}

In addition to the plain wall finishes that have been described, there are a nunber of other decorative eifects that can be achieved with paint and a few accessories such as a stipling brush, a sponge, or a crumpled roll of paper. The roll surface is, in each case, primed and sealed before any of the special coatings are applied.

Texture. Textured effects can be obtained by the use of plastic paint nade for this purpose in either the oil-base or water-base type. These are simply heavy-bodied materials which Yield a filn of sufficient thickness on the wall so that when troweled in a special nanner or worked with the flat sicle of a paint brush or textured in various other wy's, a raised irregular design is obtrined.

Stipple- A stippled effect is obtained in much the sare manner by using a long bristled brush designed for the purpose wlich is tamed against the applied paint filn before it has aried. The consistency of paint to be stippled is thicker than that of ordinary wall paint but slightly thinner than plastic paint. The result of a properly done stippling job is a plonsing, uniform appearance free fron brush maks and, to an extent, wal surface imperfections.

Mottlea tro-tone. Tro-tone effects nay be obtained in various ways. Oneof the simplest is to apply over a dried under coat of the desired collor a second cont of different color and while the latter is still net roll a crumled wad of newspaper about one foot long ifrmy over the surface. It is best to begin at the ceiling and work dom, using fresh newspaper for each strip and overlapping slightly. A two-color appenrnce of irregular design results from the wet paint being pidyed up by the rolled. nevspaper, A sonewhat sinilar effect ny be obtained by applying the topcont of paint rith the flat side or a sponge. The technique consists of floring a smil amount of the colored paint on a flat surface and then picking up sone of the paint rith the raterm darpened sponge, which is then patted. lightly agninst the rall. A colored pattern is thus applied wich should be varied by changing the position of the sponge in the hand.

Glaze, Tiffany blend.- Glazed and blended effects are obtained by the use of flatting oil nixed tith the desired colors in oil. An antique glaze is produced by applying the flatting oil colored as desired over the dry background color. This is then riped lightly with a ball of cheesecloth. The gilaze remainm ing in the depressions gives an antique appearance. The popular Tiffany blend is obtained by coating the light colorca ray undercont with flotting oil over an area of about 25 squnre feet at a time and then spotting the wet area with colors in oil thinned with flatting oil. A piece of cheesecloth is then used to blend the colors, using a circular motion. The entire surface is then patted lightly with cheesecloth to complote the blending. 


\section{PUBLICATIOITS}

The following publications relite sonerhat to the subject under discussion and infornation is given as to how they my be. obtained:

\section{Letter Circulars;}

LC445, Painting of stean and hot water radiators. LC4839, Inside rall paint for chemical laboratories. LC747, Paintins exterior ralls of porous masonry. LC748, Reiinishing vood furniture. LC750, Finishes for concrete iloors. LCS1O, The painting of exterior rood surfaces. LCos13, Dampess in basenents nnt ground floors. LC831, The painting of exterior metrl surfnces.

(Letter Circulars na be obtained Iree fron the National Burcau of Standaris).

Federnl Specifications;

TT-E-506a, Enariel; Interior, Gloss, 'Light-Tints and White TT-E-508, Enanel; Interior, Semicloss, Tints anc Thite TT-E-491, Enmel; Gloss, Synthetic (for lietal and Wood. Hospital Furniture)

TT-P-23a, Paint; Cold-Wrter, Interior, Light-Iints and Thite

TT-P-47, Paint; Oi1, Interior, One-Co-t-Flat

TT-P-510, Paint; Oil, Interior, EGgenel-FInt Finish Tr-P-56́, Paint; Priner-Senler.(For) Plnster and Tallboard

(These Federal specifications are priced at. 5 cents each and my be obtained from the Superintendent of Docunents, Washington 25, D. C.)

Paint Innual With Particular Reference to Federal Specifi-

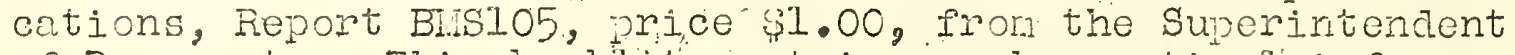
of Docunents. This booklet contains much practical informtion on paint and painting. 